\title{
Pengembangan Aplikasi Manajemen Pelatihan Laboratorium Software Engineering Di Fakultas Teknik Sistem Komputer
}

\author{
Faiz Risaludin Islami ${ }^{1)}$, Kodrat Iman Satoto ${ }^{2)}$, Rinta Kridalukmana ${ }^{2)}$ \\ Jurusan Sistem Komputer, Fakultas Teknik, Universitas Diponegoro \\ Jl. Prof. Sudharto, Tembalang, Semarang, Indonesia
}

\begin{abstract}
System computer engineering of Diponegoro University has a software engineering laboratory fonctioned to provide the learning and training activities in order to give the opportunity for the students, to examine and to apply the theory or the research and the verification scientifical subject study or a part of certain subject study. The probleme emerge in this training is less the information about the training accepted by the society who willing to attend the training at the software engineering laboratory. In propose, to solve all the problemes appear, the writer make a Management Trainee Developement Application System of Software Engineering Laboratory at Faculty of System Computer Engineering gave a complete information about the training and the registration in software engineering laboratory.

Management Trainee Application of Software Engineering Laboratory at Faculty of System Computer Engineering is an application based on website, made by using the program language PHP in scope Framework Code Igniter, and also MySQL for database. The developement methode used the waterfall methode, while designing the application used the UML modele.

The result from this application is the realization an application based on website which is abble to manage the trainee data in software engineering laboratory, for example to manage the participant training data, the list of training data, the time schedule training data, admin data, the participant traininh data along the completed training History data.
\end{abstract}

Keywords: Laboratory, Management applications, PHP, Framework Code Igniter

\section{Pendahuluan}

$\mathrm{P}$ rogram studi sistem komputer Universitas Diponegoro memiliki laboratorium software engineering yang berfungsi memberikan kegiatan pembelajaran yang bertujuan agar mahasiswa mendapat kesempatan untuk menguji dan mengaplikasikan teori atau penyelidikan dan pembuktian ilmiah matakuliah atau bagian matakuliah tertentu, di samping itu laboratorium software engineering juga memberikan pelatihan bagi mahasiswa dan juga masyarakat pada umumnya. Permasalahan yang timbul dalam pelatihan ini adalah kurangnya informasi yang diterima masyarakat yang ingin mengikuti pelatihan. Disamping itu, masyarakat yang membutuhkan informasi yang lebih jelas tentang pelatihan ini harus datang di laboratorium software engineering. Hal ini sangat tidak efisien, karena membutuhkan waktu untuk datang ke laboratorium dan hanya dapat dikunjungi pada saat jam kerja.

Untuk mengatasi semua permasalahan yang ada, dibuat sebuah sistem aplikasi manajemen pelatihan yang memberikan informasi lengkap tentang pelatihan dan pendaftaran di laboratorium software engineering. Keuntungan yang diperoleh dengan dikembangkannya sistem ini antara lain, untuk masyarakat tidak perlu datang ke laboratorium hanya untuk mendapatkan informasi dan melakukan pendaftaran tanpa terbatas oleh waktu jam kerja. Karena sistem ini dapat diakses kapan dan di mana saja melalui internet. Sistem ini juga memberikan keuntungan admin dalam mengelola informasi maupun data yang ada pada aplikasi manajemen pelatihan laboratorium software engineering.

\section{LANDASAN TEORI}

\section{A. Sistem Informasi}

Sistem informasi dapat didefinisikan sebagai berikut :

a. Suatu sistem yang dibuat oleh manusia yang terdiri dari komponen-komponen dalam organisasi untuk mencapai suatu tujuan yaitu menyajikan informasi.

b. Sekumpulan prosedur organisasi yang pada saat dilaksanakan akan memberikan informasi bagi pengambil keputusan dan atau untuk mengendalikan organisasi.

c. Suatu sistem di dalam suatu organisasi yang mempertemukan kebutuhan pengolahan transaksi, mendukung operasi, bersifat manajerial dan kegiatan 
strategi dari suatu organisasi dan menyediakan pihak luar tertentu dengan laporan-laporan yang diperlukan.

Organisasi menggunakan sistem informasi untuk mengolah transaksi-transaksi, mengurangi biaya dan menghasilkan pendapatan sebagai salah satu produk atau pelayanan mereka. Bank menggunakan sistem informasi untuk mengolah cek-cek nasabah dan membuat berbagai laporan rekening koran dan transaksi yang terjadi. Perusahaan menggunakan sistem informasi untuk mempertahankan persediaan pada tingkat paling rendah agar konsisten dengan jenis barang yang tersedia.

Sebagian sistem informasi berlandaskan komputer terdapat di dalam suatu organisasi dalam berbagai jenis. Anggota organisasi adalah pemakai informasi yang dihasilkan sistem tersebut termasuk manajer yang bertanggung atas pengalokasian sumber daya untuk pengembangan dan pengoperasian perusahaan. ${ }^{[3]}$

\section{B. Software Development Life Cycle}

SDLC atau Software Development Life Cycle atau sering disebut juga System Development Life Cycle adalah proses mengembangkan atau mengubah suatu sistem perangkat lunak dengan menggunakan modelmodel dan metodologi yang digunakan orang untuk mengembangkan sistem-sistem perangkat lunak sebelumnya (berdasarkan best practice atau cara-cara yang sudah teruji baik).

Tahapan-tahapan yang ada pada SDLC secara global adalah sebagai berikut :

a. Inisiasi (initiation)

b. Pengembangan konsep sistem (system concept development)

c. Perencanaan (planning)

d. Analisis kebutuhan (requirements analysis)

e. Desain (design)

f. Pengembangan (development)

g. Integrasi dan pengujian (integration and test)

h. Implementasi (implementation)

i. Operasi dan pemeliharaan (operations and maintenance)

j. $\quad$ Disposisi (disposition) ${ }^{[1]}$

\section{Model Waterfall}

Model SDLC air terjun (waterfall) sering juga disebut model sekuensial linier (sequential linear) atau alur hidup klasik (classic life cycle). Model air terjun menyediakan pendekatan alur hidup perangkat lunak secara sekuensial atau terurut dimulai dari analisis, desain, pengodean, pengujian, dan tahap pendukung (support).

Kenyataannya sangat jarang model air terjun dapat dilakukan sesuai alurnya karena sebab sebagai berikut: a. Perubahan spesifikasi perangkat lunak terjadi di tengah alur pengembangan.

b. Sangat sulit bagi pelanggan untuk mendefinisikan semua spesifikasi di awal alur pengembangan. Pelanggan sering kali butuh contoh (prototype) untuk menjabarkan spesifikasi kebutuhan sistem lebih lanjut.

c. Pelanggan tidak mungkin bersabar mengakomodasi perubahan yang diperlukan di akhir alur pengembangan.

Sistem manajemen adalah suatu interaksi atau kerjasama untuk melakukan fungsi pengolahan data menjadi bentuk yang penting bagi penerimanya dan mempunyai kegunaan sebagai dasar dalam pengambilan keputusan yang dapat dirasakan akibatnya secara langsung saat itu juga atau secara tidak langsung pada saat mendatang. Sehingga peranan Sistem Informasi Manajemen dapat digunakan untuk mencari atau memperoleh informasi, diperlukan adanya data dan unit pengolah data. ${ }^{[7]}$

\section{D. $E R D$}

Pemodelan awal basis data yang paling banyak digunakan adalah menggunakan Entity Relationship Diagram (ERD). ERD dikembangkan berdasarkan teori himpunan dalam bidang matematika. ERD digunakan untuk pemodelan basis data relasional. Sehingga jika penyimpanan basis data menggunakan OODBMS maka perancangan basis data tidak perlu menggunakan ERD. ${ }^{[1]}$

\section{E. $U M L$}

UML adalah bahasa spesifikasi standar yang dipergunakan untuk mendokumentasikan, menspesifikasikan dan membangun perangkat lunak. UML merupakan metodologi dalam mengembangkan sistem berorientasi objek dan juga merupakan alat untuk mendukung pengembangan sistem. UML saat ini sangat banyak dipergunakan dalam dunia industri yang merupakan standar bahasa pemodelan umum dalam industri perangkat lunak dan pengembangan sistem. ${ }^{[4]}$

\section{F. Use Case}

Use Case Diagram merupakan pemodelan untuk kelakuan (behavior) sistem informasi yang akan dibuat. Use Case mendeskripsikan sebuah interaksi antara satu atau lebih aktor dengan sistem informasi yang akan dibuat. Dapat dikatakan Use Case digunakan untuk mengetahui fungsi apa saja yang ada di dalam sistem informasi dan siapa saja yang berhak menggunakan fungsi-fungsi tersebut. ${ }^{[4]}$

\section{G. Sequence diagram}

Sequence diagram menggambarkan kelakuan objek pada Use Case dengan mendeskripsikan waktu hidup 
objek dan pesan yang dikirimkan dan diterima antar objek. ${ }^{[4]}$

\section{H. Class diagram}

Class diagram merupakan hubungan antar kelas dan penjelasan detail tiap-tiap kelas di dalam model desain dari suatu sistem, juga memperlihatkan aturan-aturan dan tanggung jawab entitas yang menentukan perilaku sistem. Class diagram juga menunjukkan atribut-atribut dan operasi-operasi dari sebuah kelas dan constraint yang berhubungan dengan objek yang dikoneksikan. ${ }^{[4]}$

\section{I. $P H P$}

PHP merupakan singkatan dari Hypertext Preprocessor yang merupakan bahasa berbentuk skrip yang ditempatkan pada server dan diproses di server. Hasilnya kemudian dikirimkan ke browser klien. ${ }^{[5]}$

\section{J. Javasript}

Javascript adalah bahasa yang berbentuk kumpulan skrip yang pada fungsinya berjalan pada suatu dokumen HTML. Sepanjang sejarah internet bahasa ini adalah bahasa skrip pertama untuk web. Bahasa ini adalah bahasa pemrograman untuk memberikan kemampuan tambahan terhadap HTML dengan mengijinkan pengeksekusian perintah-perintah di sisi klien, yang artinya di sisi browser bukan di sisi server. ${ }^{[2]}$

\section{K. CSS}

CSS didesain untuk memisahkan konten dokumen dengan presentasi dokumen, termasuk elemen seperti layout, warna dan pilihan huruf (font). Pemisahan ini akan memberikan keuntungan dalam hal aksesibilitas konten, meningkatkan fleksibilitas dan memungkinkan beberapa halaman untuk berbagai format yang sama serta mampu mengurangi kompleksitas dan pengulangan dalam penulisan atau struktur konten. ${ }^{[6]}$

\section{Code Igniter}

Code Igniter adalah aplikasi open source yang berupa framework dengan model MVC (model view controller) untuk membangun website dinamis. Dengan menggunakan PHP Code Igniter akan memudahkan developer untuk membuat aplikasi web dengan cepat dan mudah dibandingkan dengan membuatnya dari awal. ${ }^{[10]}$

\section{M. $M y S Q L$}

$M y S Q L$ adalah sebuah perangkat lunak sistem manajemen basis data SQL atau DBMS yang multithread, multi-user dengan sekitar 6 juta instalasi di seluruh dunia. MySQL AB membuat $M y S Q L$ tersedia sebagai perangkat lunak gratis di bawah lisensi $G N U$ General Public Licence (GPL). Tetapi mereka juga menjual di bawah lisensi komersial untuk kasus-kasus di mana penggunaannya tida cocok dengan pengunaan GPL. ${ }^{[9]}$

\section{PERANCANGAN Sistem}

\section{A. Tahapan Perancangan Sistem}

Tahapan perancangan sistem memiliki tujuan untuk men-desain sistem baru yang dapat menyelsaikan masalah-masalah yang dihadapi organisasi atau perusahaan. Software Development Live Cycle adalah proses mengembangkan atau mengubah suatu sistem perangkat lunak dengan menggunakan model-model yang digunakan orang untuk mengembangkan sistemsistem perangkat lunak sebelumnya. Model yang digunakan dalam penelitian tugas akhir ini adalah model waterfall. Model waterfall terdiri dari 5 tahap yaitu Analisis Kebutuhan, Desain, Pengodean, Pengujian dan Pemeliharaan. ${ }^{[8]}$

\section{B. Analisis Kebutuhan}

Tahapan analisis kebutuhan dilakukan untuk menspesifikasikan kebutuhan perangkat lunak agar dapat dipahami perangkat seperti apa yang diinginkan user dan kemudian mentransformasikan ke dalam sebuah deskripsi yang jelas dan lengkap.

\section{Kebutuhan Fungsional}

Kebutuhan fungsional merupakan fungsionalitas atau layanan yang harus diberikan oleh sistem. Kebutuhan ini akan bergantung pada jenis perangkat lunak yang sedang dikembangkan, pengguna yang diharapkan menggunakan perangkat lunak tersebut dan jenis sistem yang akan digunakan. Kebutuhan fungsional dari aplikasi ini adalah:

1. Mengelola data admin

2. Membuka dan menutup jalanya pelatihan pada sistem

3. Menambahkan dan menghapus pelatihan

4. Menampilkan history pelatihan yang sudah berlangsung

5. Mengelola data peserta pelatihan.

\section{Kebutuhan non-fungsional}

Kebutuhan non-fungsional merupakan kebutuhan yang tidak langsung berhubungan dengan spesifik yang disediakan oleh sistem. Kebutuhan ini berhubungan dengan properti sistem yang muncul belakangan, seperti keandalan, waktu tanggap dan penempatan pada media penyimpanan. Batasan sistem mengenai kemampuan piranti masukan dan keluaran yang dipakai pada antarmuka sistem juga termasuk dalam kebutuhan nonfungsional. Kebutuhan non-fungsional aplikasi ini antara lain:

1. Operasional Aplikasi ini dapat berjalan lancar pada perangkat dekstop, seperti Pc (Personal computer) dan Laptop.

2. Aplikasi membutuhkan koneksi internet untuk mengubungkan data dan server. 


\section{Desain}

Tahap perancangan / desain perangkat lunak merupakan proses multi langkah dan berfokus pada beberapa atribut perangkat lunak. Proses ini berdasarkan dari analisa sebelumnya sehingga menciptakan sebuah rancangan yang sesuai dengan kebutuhan dari pihak terkait. Dalam perancangan perangkat lunak ini, digunakan Entity Relationship Diagram (ERD) untuk pemodelan basis data dan UML untuk pemodelan perangkat lunak.

1. UML

a. Usecase Diagram

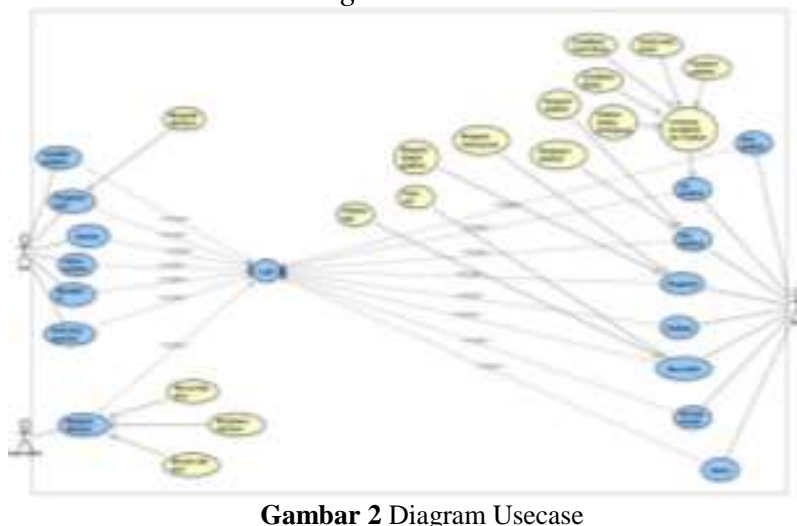

b. Class Diagram

Class diagram atau diagram kelas menggambarkan hubungan yang ada pada kelas-kelas pada aplikasi. Berikut merupakan diagram kelas aplikasi Manajemen Pelatihan Laoratorium software engineering

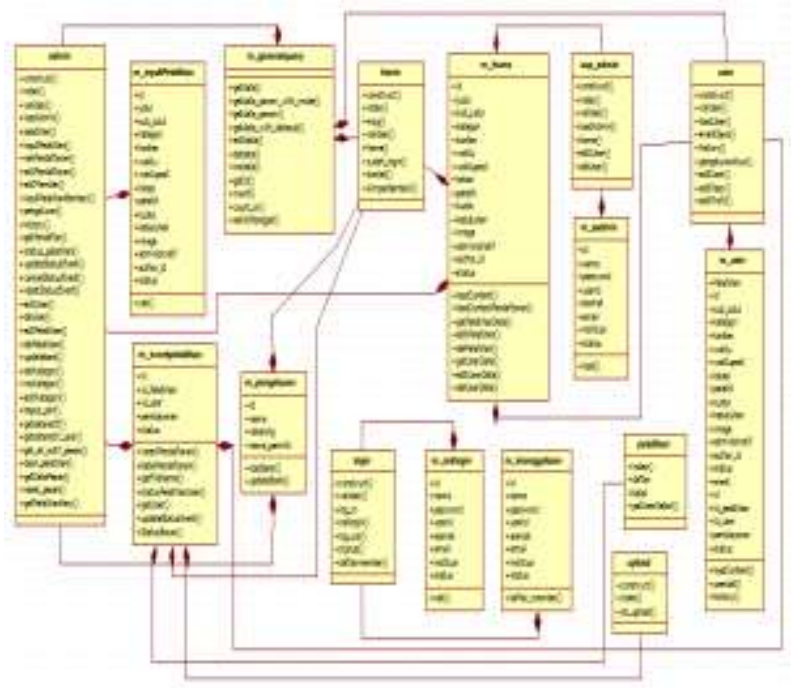

Gambar 3Diagram Kelas Aplikasi Manajemen Pelatihan Laboratorium software engginering

c. Sequence Diagram

Berkut ini adalah gambar-gambar Diagram Sequence dari Pengembangan Aplikasi Manajemen Laboratorium Software Engineering.
Gambar 4 merupakan diagram sekuensial untuk masuk ke sistem (login).

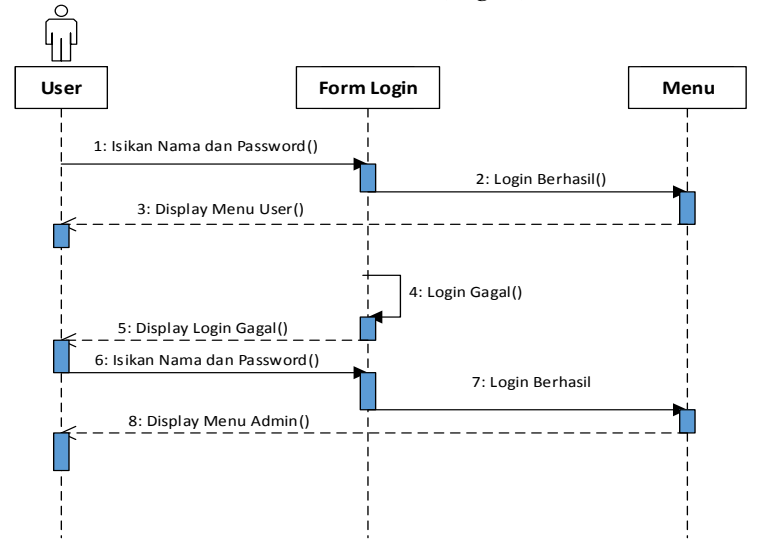

Gambar 4 Diagram sekuensial masuk ke sistem (login)

Gambar 5 merupakan diagram sekuensial dari mengelola data akun

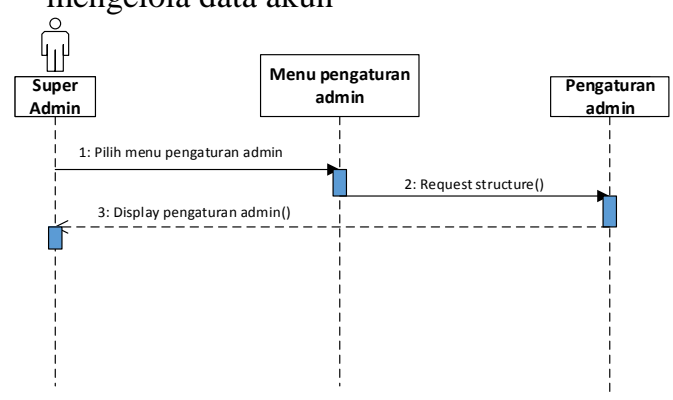

.Gambar 5 Diagram sekuensial dari mengelola data akun

Gambar 6 merupakan diagram sekuensial dari mencari data akun.

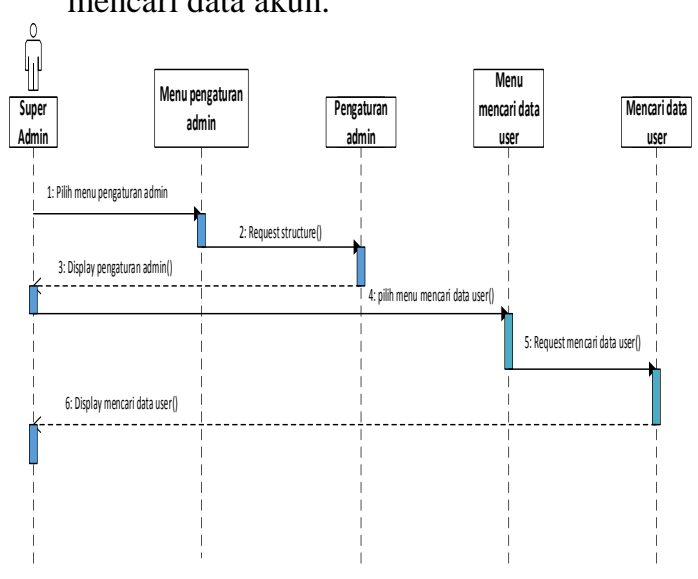

Gambar 6 Diagram sekuensial dari mencari data akun

Gambar 7 merupakan diagram sekuensial dari menghapus data user. 


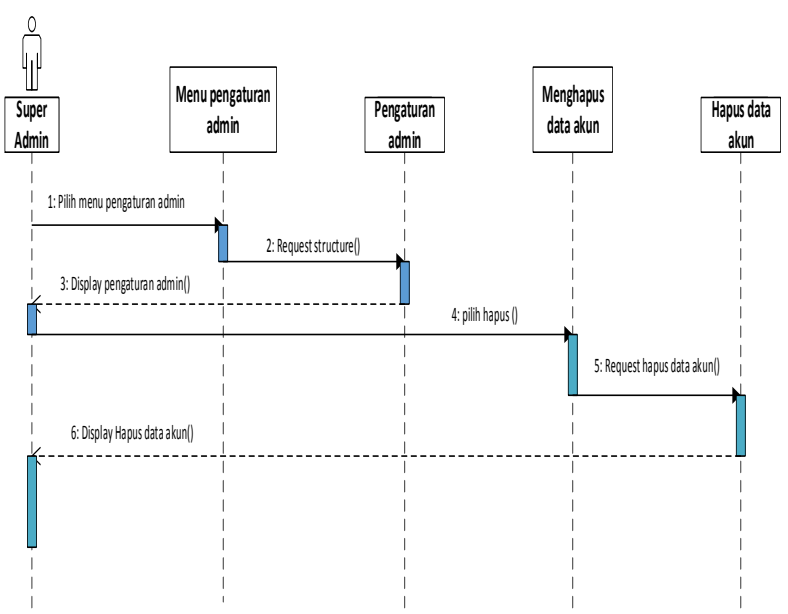

Gambar 7 Diagram sekuensial dari Menghapus data user

Gambar 8 merupakan diagram sekuensial dari merubah data akun.

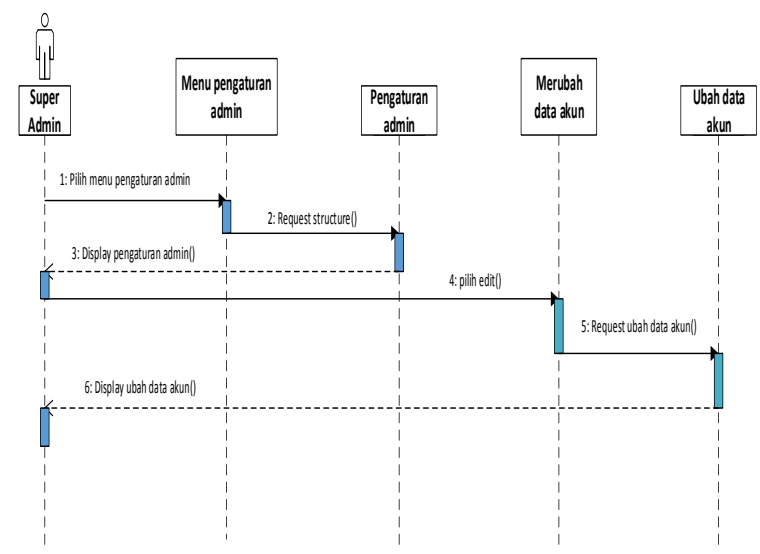

Gambar 8 Diagram sekuensial dari merubah data akun

Gambar 9 merupakan diagram sekuensial dari Input Pelatihan

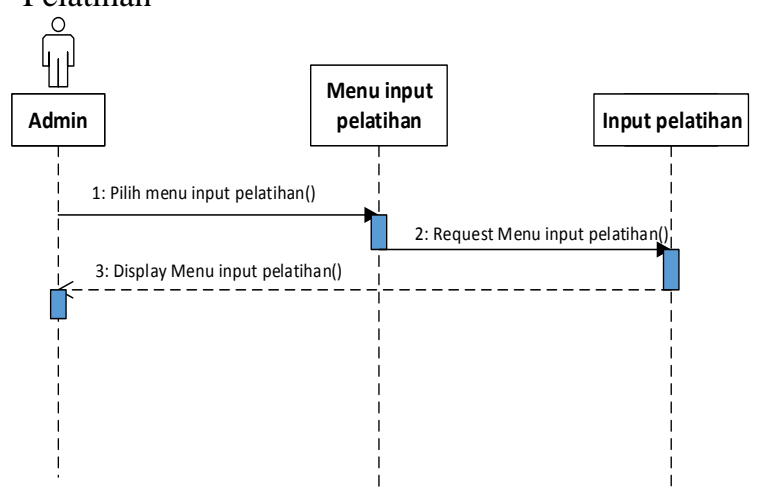

Gambar 9 Diagram sekuensial dari input pelatihan

Gambar 10 merupakan diagram sekuensial dari Cek Pelatihan

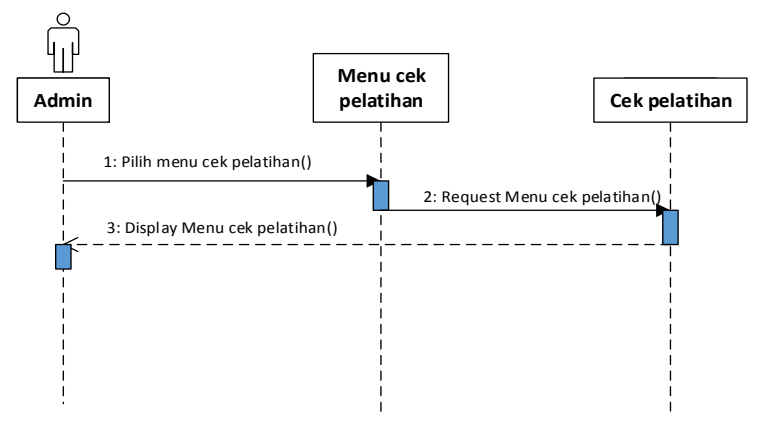

Gambar 10 Diagram sekuensial dari cek pelatihan

Gambar 11 merupakan diagram sekuensial dari monitoring dan pendaftaran pelatihan

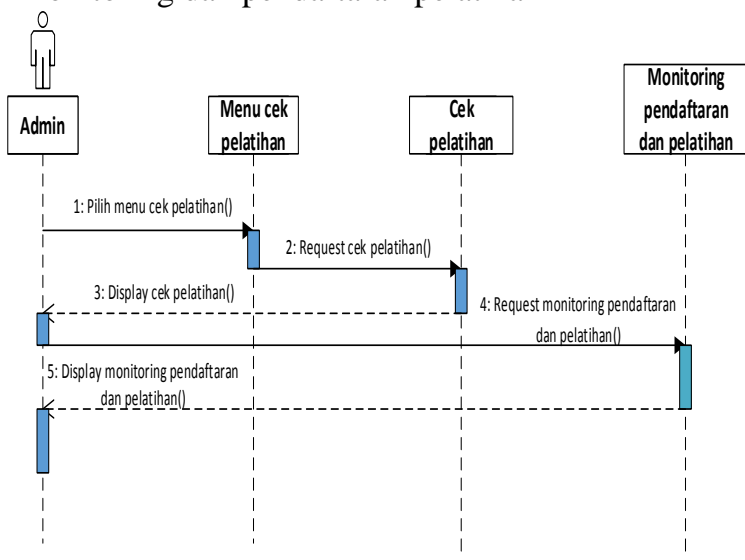

Gambar 11 Diagram sekuensial dari monitoring dan pendaftaran pelatihan

\section{IMPLEMENTASI DAN PENGUJIAN}

\section{A. Implementasi Basis Data}

Tahapan ini mengimplementasikan hasil perancangan basis pada sistem yang telah dibuat sebelumnya.

Gambar 12 merupakan contoh implementasi pada tabel Bank.

\begin{tabular}{|c|c|c|c|c|c|}
\hline & f Name & Collation & Atritivetes : & Null Defau & at Eatra \\
\hline 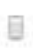 & i id $p$ & int(11) & & No None & AUTO_INCREMENT \\
\hline 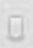 & 2 nana & vachar(2) latint_suedst_c & & No Nane & \\
\hline U & 3 rekening & vachar 38 lani _saedsh ci & & No Nare & \\
\hline L & 4 nama jemilik & (rachar [5) lain'_suedsh_c & & No: Nore & \\
\hline
\end{tabular}

Implementasi tabel yang lain ditunjukkan oleh gambar 13 sampai dengan gambar 18 . 


\begin{tabular}{|c|c|c|c|c|c|c|c|}
\hline & \# Name & Type & Collation & Atributes & S Null & Default & Extra \\
\hline (1) & $t$ id $p$ & intititol) & & & No & None & AUTO_NCPEMENT \\
\hline (1) & 2 id pelatihan & vachar(5) & leint_suedish _o & & No & Nane & \\
\hline $\mathrm{B}$ & 3 id_user & varchar(5) & lafint_swevish_e & & $\mathrm{No}$ & None & \\
\hline (6) & 4 pembayaran & varcharit(00) & ilatnt_swedish_ ce & & Yes & none & \\
\hline - & 5 status & varchar 20$\}$ & latint_swedish_ce & & $\mathrm{No}$ & nomal & \\
\hline \multicolumn{8}{|c|}{ Gambar 13 Implementasi tabel event } \\
\hline & \# Name & Type & Collation & Anributes & Null & Default & Extra \\
\hline D & 1 id 9 & inti5) & & & No & Mone & AUTO_MCREMENT \\
\hline G & 2 korten & vachar(50) : & latint_suedsh_Gi & & Yes & MLL & \\
\hline 日 & 3 id_user & varchan5) & latint_suedish_ci & & Yes & MUL & \\
\hline 8 & 4 waktus & vachar 20 , & lant_swedst_ ol & & Yes & aLt & \\
\hline$=$ & 5 resd_status & int(11) & & & $\mathrm{No}$ & 6 & \\
\hline
\end{tabular}

Gambar 14 Implementasi tabel History

\begin{tabular}{|c|c|c|c|c|c|c|}
\hline & \# Name & Type & Collation & Antributes & Null Defauh & Extra \\
\hline & 1 id & $\mathrm{nt}+2 \mathrm{O}$ & & & No Nione & AUTO_INCREMENT \\
\hline & 2 katego & varchar! & latin1__siedish_ti & & No tione & \\
\hline
\end{tabular}

Gambar 15 Implementasi tabel Kategori

\begin{tabular}{|c|c|c|c|c|c|c|c|}
\hline & I Nome & Iys: & Cotlarion & Amribunes & Null & Defouat & Extra \\
\hline B & 1 if $p$ & intetoss & & & No & Nave & AUTO_INCAEMENT \\
\hline b & -2 judal & Kartarof & Jint_randso _ci & & No & Whe & \\
\hline 10 & 3 sab judul & verchartidy & Int Lanadsh gi & & Yes & nees. & \\
\hline E & 4 kategol & Incharfact & 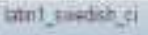 & & $Y_{65}$ & Nal. & \\
\hline 目 & 5 boveten & vartur(200) & inint_twedat_si & & No & Nove & \\
\hline 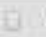 & 6 maktu & vathar $(x 6)$ & Ginl_zatednh_ei & & 16 & Mire: & \\
\hline B & 7 waktu post & varchar 20$\}$ & Itn1_swedst_ci & & $Y_{a s}$ & Neer & \\
\hline 19] & b lokas & varitartop) & latn! swatshty & & 16 & Nases & \\
\hline 目 & 9 pelatih & kschar $(30)$ & innt_awedsh_si & & No: & Nove & \\
\hline$B$ & to hoota & intey & & & Yes & neri & \\
\hline 1. & 11 kebutuhan & vartar 50 , & Sth1_gundsh_ai & & Yes & NeL & \\
\hline B & 12 image & vactariats & lant__zoudsegi & & $Y_{65}$ & Neli: & \\
\hline 尚 & 13 adninistratit & yarthat15\}: & lutnt_amedsh_si & & Yes & $\theta$ & \\
\hline (a) & 14 whos id & vaxtheis) & bint_twedst ol & & Yes & Neel: & \\
\hline & 15 status & vactar|11) & Inin1_sunfst_si & & $Y_{e s}$ & buka & \\
\hline
\end{tabular}

Gambar 16 Implementasi table pelatihan

\begin{tabular}{|c|c|c|c|c|c|c|c|}
\hline & f. Name & Type & Collation & Attributes & Null & Detauit & Extra \\
\hline [1] & 1 id $P$ & $i n(t 00)$ & & & No & None & AUTO_IRCREMENT \\
\hline 1 & 2 pesan & kngext & Gant wueskab, Et & & Yes: & mii & \\
\hline E & 3 nama & farchers:0) & Itint_swedsh_si & & Yes & MeXL & \\
\hline 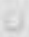 & A amall & varchandel & latint_woduth_ti & & Yes & NLEL & \\
\hline e & 5 thlp & varthan $(15)$ & Iatin1_swedsh_zi & & Yes & mere & \\
\hline B & 6 wabby & vartarepi & Lant_sweodih ar & & Ye & wixe & \\
\hline . & 7 iead statuse & $n+127$ & & & No & Q & \\
\hline
\end{tabular}

Gambar 17 Implementasi tabel pesan_umum

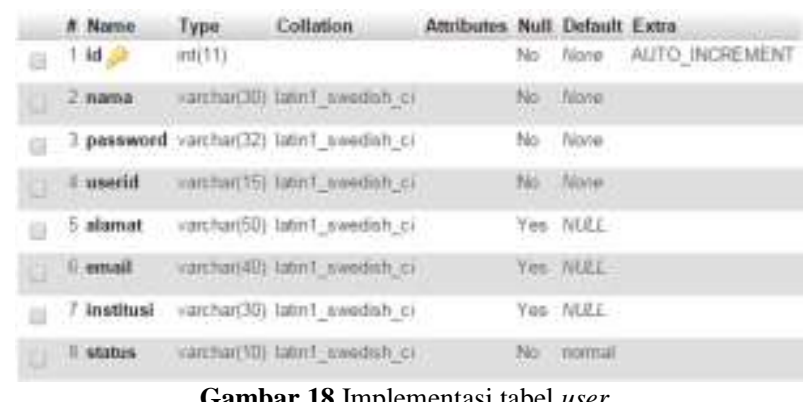

Gambar 18 Implementasi tabel user

\section{B. Implementasi Antarmuka}

Berikut ini merupakan antarmuka yang dimiliki Aplikasi Manajemen Pelatihan Laboratorium:

1. Halaman Login

Berisi form untuk melakukan login ke aplikasi dengan memasukkan username dan password, tampilan seperti pada gambar 19.

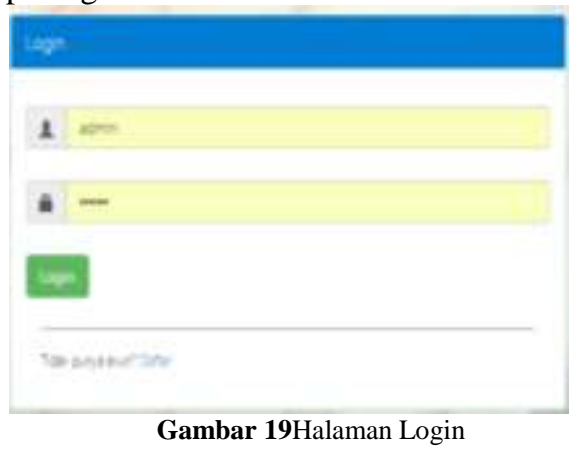

2. Halaman User

Berisi fitur untuk mendaftar pelatihan, tampilan seperti pada Gambar 20.

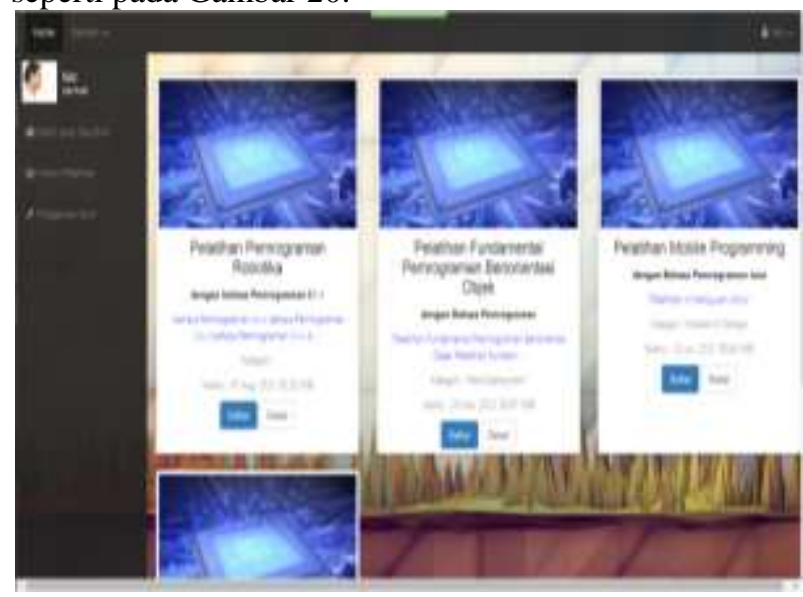

Gambar20Halaman Pengguna

3. Halaman Admin

Berisi fitur untuk meilhan pesan user dan pelatihan baru, tampilan seperti pada Gambar 21. 


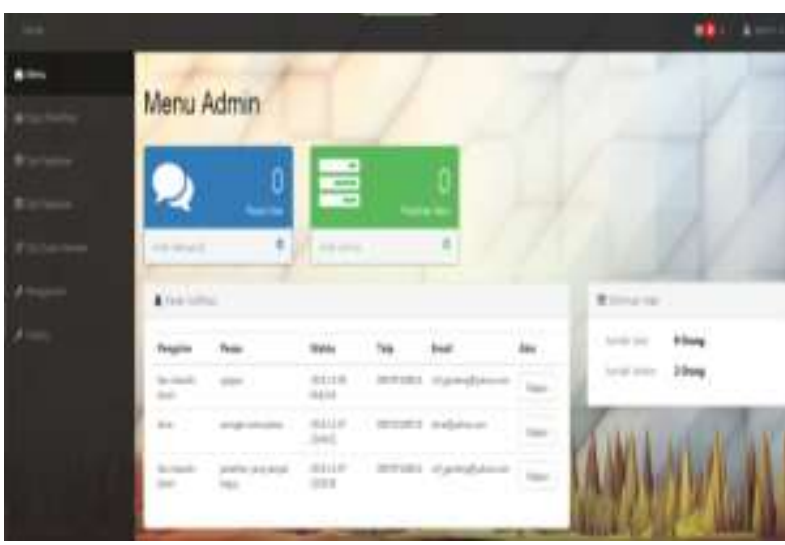

Gambar 21Halaman Admin

4. Halaman Input pelatihan

Berisi fitur untuk menambahkan pelatihan baru, tampilan seperti pada Gambar 22.

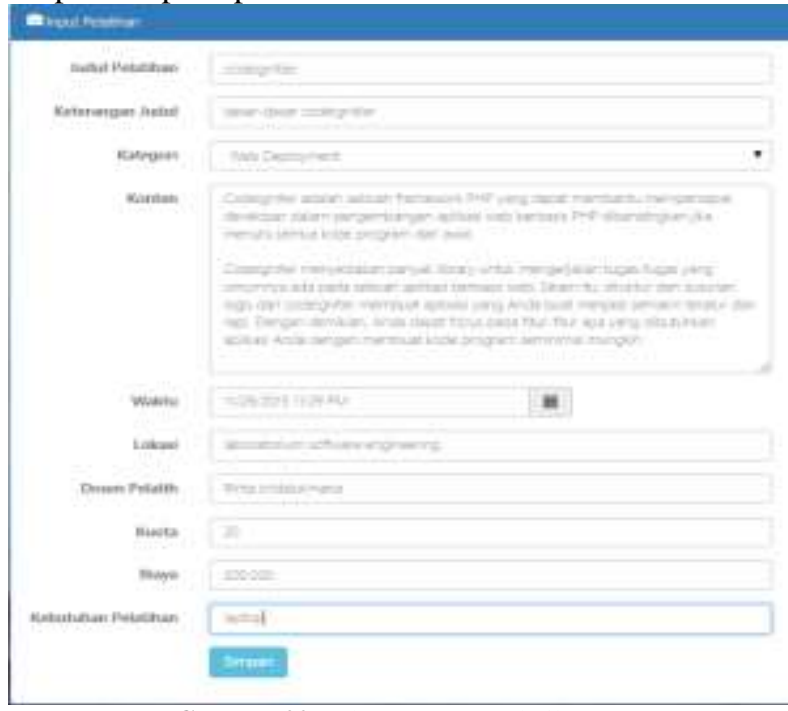

Gambar 22 Halaman Input Pelatihan

\section{Halaman Cek Pelatihan}

Berisi fitur untuk mengelola pendaftran dan waktu pelatihan, tampilan seperti pada Gambar 23.

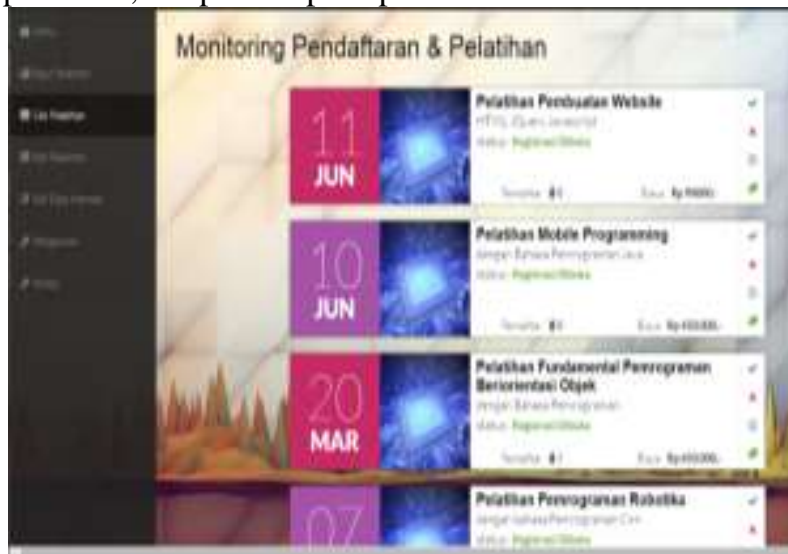

Gambar 23 Halaman Cek Pelatihan
6. Halaman Edit Pelatihan

Berisi fitur untuk megubah atau menghapus pelatihan, tampilan seperti pada Gambar 24.

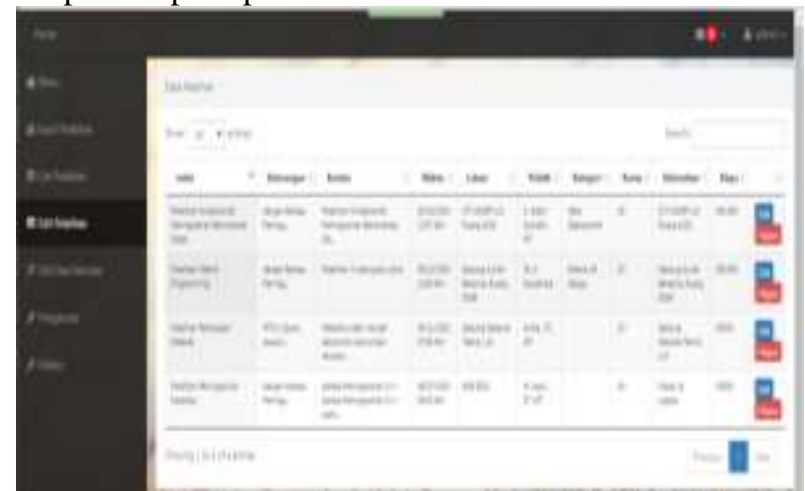

Gambar 24 Halaman Edit Pelatihan

7. Halaman Edit Data Member

Berisi fitur untuk mengelola user, tampilan seperti pada Gambar 25.

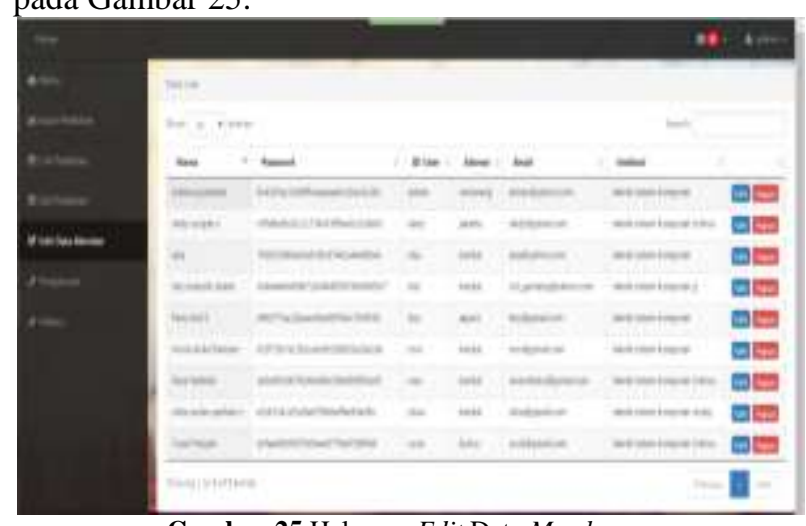

Gambar 25 Halaman Edit Data Member

8. Halaman Menu Pengaturan Admin

Berisi fitur untuk mengelola nomor rekening bank dan kategori pelatihan, tampilan seperti pada Gambar 26.

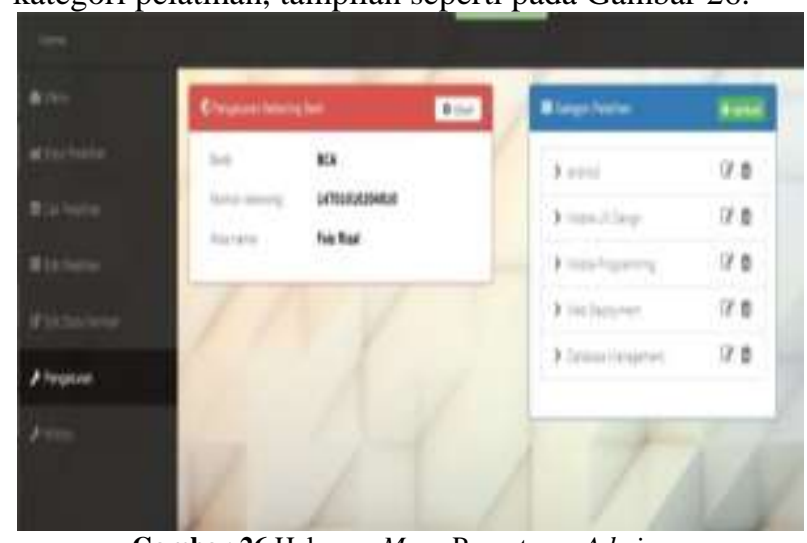

Gambar 26 Halaman Menu Pengaturan Admin

9. Halaman History Admin

Berisi fitur untuk melihat semua aktifitas yang dilakukan admin, tampilan seperti pada Gambar 27. 


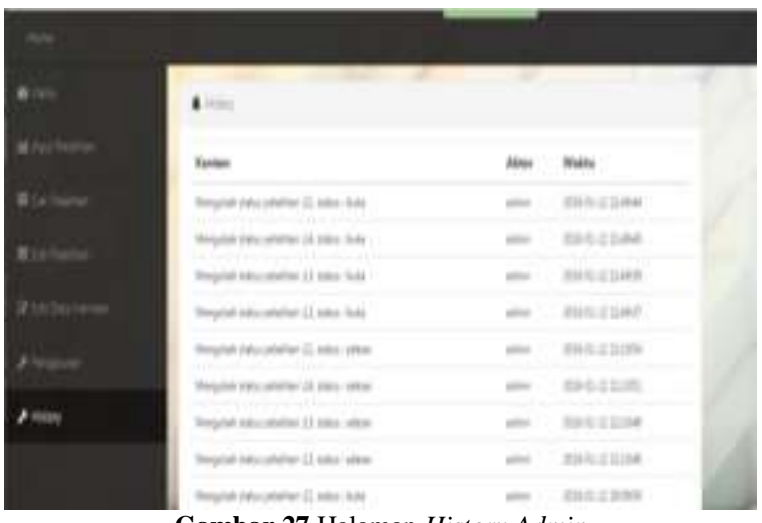

Gambar 27 Halaman History Admin

\section{Halaman Superadmin}

Berisi fitur untuk mengelola admin dan user, tampilan seperti pada Gambar 28.

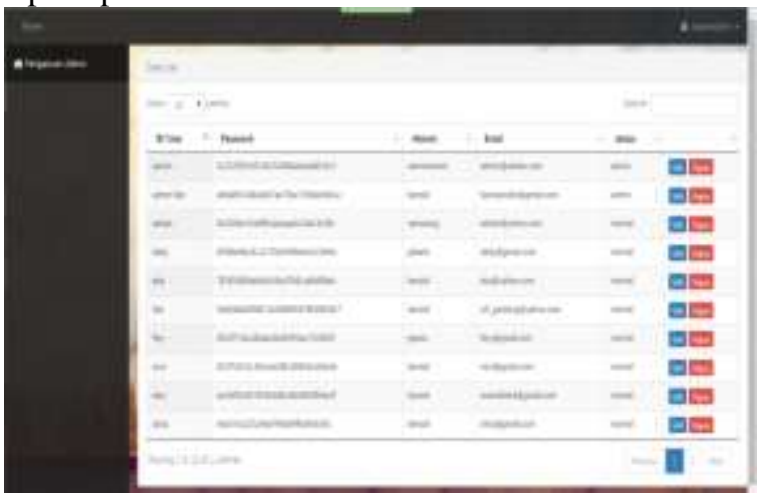

Gambar 28Halaman Superdmin

\section{Pengujian}

Proses pengujian dilakukan menggunakan metode black-box berdasarkan fungsi dari aplikasi yang tertera pada diagram use case.

Tabel-tabel di bawah ini merupakan ringkasan dari pengujian yang telah dilakukan. Pertama adalah Tabel 1 yang merupakan ringkasan pengujian yang berhubungan dengan pengelolaan data User.

Tabel 1Pengujian Blackbox

\begin{tabular}{|c|c|c|c|}
\hline $\begin{array}{c}\text { Nama } \\
\text { Pengujian }\end{array}$ & Bentuk Pengujian & $\begin{array}{c}\text { Hasil yang } \\
\text { diharapkan }\end{array}$ & $\begin{array}{c}\text { Hasil } \\
\text { Pengujian }\end{array}$ \\
\hline $\begin{array}{l}\text { Pengujian } \\
\text { login }\end{array}$ & $\begin{array}{lr}\text { Memasukkan } & \\
\text { username } & \text { dan } \\
\text { password } & \text { yang } \\
\text { digunakan } & \text { untuk } \\
\text { login } & \end{array}$ & $\begin{array}{l}\text { Muncul } \\
\text { halaman } \\
\text { utama user }\end{array}$ & Berhasil \\
\hline $\begin{array}{l}\text { Pengujian } \\
\text { mencari } \\
\text { data } \text { user }\end{array}$ & $\begin{array}{l}\text { Memasukan nama } \\
\text { user yang akan } \\
\text { dicari di menu daftar } \\
\text { user }\end{array}$ & $\begin{array}{lr}\text { Muncul nama } \\
\text { user yang } \\
\text { akan dicari di } \\
\text { menu daftar } \\
\text { user }\end{array}$ & Berhasil \\
\hline $\begin{array}{l}\text { Pengujian } \\
\text { ubah data } \\
\text { user }\end{array}$ & $\begin{array}{lr}\text { Memilh } & \text { data } \\
\text { pengguna } & \text { yang } \\
\text { tersedia } & \text { dan } \\
\text { mengubah } & \\
\text { informasinya } & \end{array}$ & $\begin{array}{l}\text { Muncul pesan } \\
\text { data pengguna } \\
\text { berhasil } \\
\text { diperbarui dan } \\
\text { data yang baru } \\
\text { muncul dalam }\end{array}$ & Berhasil \\
\hline
\end{tabular}

\begin{tabular}{|l|l|l|l|}
\hline & & daftar & \\
\hline Pengujian & Memilih data & Muncul pesan & Berhasil \\
hapus data & pengguna tertentu & data pengguna & \\
user & dan menghapus data & berhasil dengan & dihapus dan \\
& tersebut dombol & data yang & \\
& mengklik tihapus & \\
& hapus & $\begin{array}{l}\text { menghilang } \\
\text { dari daftar }\end{array}$ & \\
& &
\end{tabular}

Tabel 2 Pengujian Blackbox (lanjutan)

\begin{tabular}{|c|c|c|c|}
\hline $\begin{array}{l}\text { Nama } \\
\text { Pengujian }\end{array}$ & Bentuk Pengujian & $\begin{array}{l}\text { Hasil yang } \\
\text { diharapkan }\end{array}$ & $\begin{array}{l}\text { Hasil } \\
\text { Pengujian }\end{array}$ \\
\hline $\begin{array}{l}\text { Pengujian } \\
\text { login }\end{array}$ & $\begin{array}{lr}\text { Memasukkan } & \\
\text { username } & \text { dan } \\
\text { password } & \text { yang } \\
\text { digunakan } & \text { untuk } \\
\text { login } & \end{array}$ & $\begin{array}{l}\text { Muncul } \\
\text { halaman utama } \\
\text { user }\end{array}$ & Berhasil \\
\hline $\begin{array}{l}\text { Pengujian } \\
\text { menu } \\
\text { admin }\end{array}$ & $\begin{array}{l}\text { Memilih pesan user } \\
\text { dan pelatihan baru } \\
\text { yang ada pada menu } \\
\text { admin }\end{array}$ & $\begin{array}{l}\text { Maka akan } \\
\text { muncul menu } \\
\text { pesan } \text { user dan } \\
\text { menu pelatihan } \\
\text { baru }\end{array}$ & Berhasil \\
\hline $\begin{array}{l}\text { Pengujian } \\
\text { input } \\
\text { pelatihan }\end{array}$ & $\begin{array}{l}\text { Memilih input } \\
\text { pelatihan maka akan } \\
\text { mucul form input } \\
\text { pelatihan, setelah } \\
\text { selesai meginput } \\
\text { klik tombol save }\end{array}$ & $\begin{array}{l}\text { Muncul pesan } \\
\text { input berhasil, } \\
\text { dan muncul } \\
\text { pelatihan baru }\end{array}$ & Berhasil \\
\hline $\begin{array}{l}\text { Pengujian } \\
\text { cek } \\
\text { pelatihan }\end{array}$ & $\begin{array}{lr}\text { Memilih } & \text { tombol } \\
\text { pendaftar maka akan } \\
\text { muncul } & \text { jumlah } \\
\text { pendaftar } & \text { dan } \\
\text { mengelola } & \text { status } \\
\text { pelatiahan } & \end{array}$ & $\begin{array}{l}\text { Pendaftar } \\
\text { pelatihan telah } \\
\text { terdftar dan } \\
\text { status pelatihan } \\
\text { bisa dirubah. }\end{array}$ & Berhasil \\
\hline $\begin{array}{l}\text { Pengujian } \\
\text { edit } \\
\text { pelatihan }\end{array}$ & $\begin{array}{l}\text { Memilih pelatihan } \\
\text { yang akan diedit dan } \\
\text { dihapus }\end{array}$ & $\begin{array}{l}\text { Maka akan } \\
\text { muncul form } \\
\text { edit pelatihan, } \\
\text { isi semua form } \\
\text { dan klik } \\
\text { tombol save }\end{array}$ & Berhasil \\
\hline $\begin{array}{l}\text { Pengujain } \\
\text { Edit data } \\
\text { member }\end{array}$ & $\begin{array}{l}\text { Memilih user yang } \\
\text { akan diedit atau } \\
\text { dihapus di mеnu dat } \\
\text { user }\end{array}$ & $\begin{array}{lr}\text { maka } & \text { akan } \\
\text { mucul } & \text { menu } \\
\text { edit } & \text { user dan } \\
\text { ketik } & \text { simpan } \\
\text { setelah } & \text { selesai, } \\
\text { dan tombol } & \text { tomb } \\
\text { hapus untuk } & \text { hapus } \\
\text { user }\end{array}$ & Berhasil \\
\hline $\begin{array}{l}\text { Pengujian } \\
\text { Pengaturan }\end{array}$ & $\begin{array}{lr}\text { Mengubah } & \text { kategori } \\
\text { pelatihan } & \text { dan } \\
\text { mengubah } & \text { rekening } \\
\text { bank } & \end{array}$ & $\begin{array}{l}\text { Kategori } \\
\text { pelatihan } \\
\text { berhasil diubah } \\
\text { dan rekening } \\
\text { bank }\end{array}$ & Berhasil \\
\hline $\begin{array}{l}\text { Pengujian } \\
\text { History }\end{array}$ & Memilih History & $\begin{array}{lr}\text { Maka akan } \\
\text { muncul history } \\
\text { seluruh } \\
\text { kegiatan apa } \\
\text { saja yang } \\
\text { dilakukan } & \text { oleh } \\
\text { admin } & \end{array}$ & Berhasil \\
\hline $\begin{array}{l}\text { Pengujian } \\
\text { notifikasi }\end{array}$ & $\begin{array}{l}\text { Memilih } \\
\text { notifikasi }\end{array}$ & $\begin{array}{lr}\text { Maka } & \text { akan } \\
\text { muncul } & \text { menu } \\
\text { seluruh } & \text { pesan } \\
\text { user } & \end{array}$ & Berhasil \\
\hline
\end{tabular}


Tabel 3 Pengujian Blackbox (lanjutan)

\begin{tabular}{|c|c|c|c|}
\hline $\begin{array}{l}\text { Nama } \\
\text { Pengujian }\end{array}$ & Bentuk Pengujian & $\begin{array}{l}\text { Hasil yang } \\
\text { diharapkan }\end{array}$ & $\begin{array}{l}\text { Hasil } \\
\text { Pengujian }\end{array}$ \\
\hline $\begin{array}{l}\text { Pengujian } \\
\text { login }\end{array}$ & $\begin{array}{lr}\text { Memasukkan } & \\
\text { username } & \text { dan } \\
\text { password } & \text { yang } \\
\text { digunakan } & \text { untuk } \\
\text { login } & \\
\end{array}$ & $\begin{array}{l}\text { Muncul } \\
\text { halaman utama } \\
\text { user }\end{array}$ & Berhasil \\
\hline $\begin{array}{l}\text { Pengujian } \\
\text { mendaftar } \\
\text { Id }\end{array}$ & $\begin{array}{l}\text { Memilih tombol } \\
\text { daftar maka akan } \\
\text { muncul form daftar, } \\
\text { isi semua dan klik } \\
\text { daftar }\end{array}$ & $\begin{array}{l}\text { Muncul pesan } \\
\text { Pendaftaran } \\
\text { berhasil }\end{array}$ & Berhasil \\
\hline $\begin{array}{l}\text { Pengujian } \\
\text { memilih } \\
\text { pelatihan }\end{array}$ & $\begin{array}{l}\text { Memilih Pelatihan } \\
\text { kemudian r klik } \\
\text { daftar, dan upload } \\
\text { bukti pembayaran } \\
\text { pelatihan }\end{array}$ & $\begin{array}{l}\text { Muncul pesan } \\
\text { menunggu } \\
\text { konfirmasi } \\
\text { pada pelatihan } \\
\text { yang didaftar }\end{array}$ & Berhasil \\
\hline $\begin{array}{l}\text { Pengujian } \\
\text { bantuan }\end{array}$ & $\begin{array}{lr}\text { Memilih } & \text { bantuan } \\
\text { dan akan } & \text { muncul } \\
\text { tombol } & \text { hubungi } \\
\text { admin. } & \end{array}$ & $\begin{array}{l}\text { Muncul form } \\
\text { pesan hubungi } \\
\text { admin, isikan } \\
\text { kan semua dan } \\
\text { tekan tombol } \\
\text { kirim }\end{array}$ & Berhasil \\
\hline $\begin{array}{l}\text { Pengujian } \\
\text { event yang } \\
\text { saya ikuti }\end{array}$ & $\begin{array}{l}\text { Memilih event yang } \\
\text { saya ikuti }\end{array}$ & $\begin{array}{lr}\begin{array}{l}\text { Maka } \\
\text { muncul }\end{array} \\
\text { pelatihan } & \text { yang } \\
\text { diikuti } & \text { oleh } \\
\text { user } & \\
\end{array}$ & Berhasil \\
\hline $\begin{array}{l}\text { Pengujian } \\
\text { history } \\
\text { Pelatihan }\end{array}$ & $\begin{array}{l}\text { Memilih history } \\
\text { pelatihan }\end{array}$ & $\begin{array}{l}\text { Maka akan } \\
\text { muncul } \\
\text { pelatihan- } \\
\text { pelatihan yang } \\
\text { pernah di ikuti } \\
\text { oleh user dan } \\
\text { sudah selesai }\end{array}$ & Berhasil \\
\hline $\begin{array}{l}\text { Pengujian } \\
\text { pengaturan } \\
\text { Akun }\end{array}$ & $\begin{array}{l}\text { Mengubah } \\
\text { pengaturan Id dan } \\
\text { profil, }\end{array}$ & $\begin{array}{l}\text { Maka akan } \\
\text { muncul edit } \\
\text { profil dan klik } \\
\text { simpan, dan } \\
\text { pengaturan Id } \\
\text { setelah selesai } \\
\text { klik simpan }\end{array}$ & Berhasil \\
\hline
\end{tabular}

\section{PENUTUP}

Kesimpulan dan saran dari hasil penelitian dan pembahasan adalah sebagai berikut.

\section{A. Kesimpulan}

Dari hasil pengujian dan analisis Pengembangan aplikasi manajemen pelatihan laboratorium software engineering di fakultas teknik sistem komputer, dapat disimpulkan beberapa hal sebagai berikut:

1. Berdasarkan hasil pengujian aplikasi menggunakan metode Black-box, seluruh fungsi menu yang ada dalam aplikasi telah berhasil sesuai dengan fungsinya.
2. Aplikasi ini mempunyai 3 user yaitu, super admin, admin dan member

3. Aplikasi ini memiliki fitur notifikasi pada admin yang berfungsi memberikan pemberitahuan apabalia ada keluhan atau pengaduan dari user tentang pelatihan.

4. Super admin berwenang untuk mengelola data akun.

5. Admin di sini bertugas mengelola pendaftar pelatihan dan mengatur jalanya pelatihan.

6. Aplikasi ini dapat melakukan fungsi pendaftaran pelatihan dan konfirmasi pembayaran secara online.

\section{B. Saran}

Terdapat saran dari hasil penelitian yaitu sebagai berikut :

1. Pengembangan aplikasi manajemen pelatihan laboratorium software engineering di fakultas teknik sistem komputer dapat dikembangkan ke versi mobile.

2. Menambahkan notifikasi pada user sebagai informasi pendaftaran pelatihan, apakah pendaftaran pelatihan user sudah diterima atau ditolak admin.

\section{DAFTAR PUSTAKA}

[1] A.S, Rosa dan Shalahuddin, M., Modul Pembelajaran Rekayasa Perangkat Lunak (Terstruktur dan Berorientasi Objek), Modula, Bandung, 2011.

[2] Adi, A.P dan Sanjay, R., Web Makin Dahsyat dengan JQuery, Kompas Gramedia. Semarang, 2012.

[3] Bin Ladjamudin, Al-Bahra, Analisis dan Desain Sistem Informasi, Graha Ilmu, Yogyakarta, 2005.

[4] Gata, Windu dan Gata, Grace., Sukses Membangung Aplikasi Penjualan dengan Java, PT Elex Media Komputindo, Jakarta, 2013.

[5] Hirin A.M dan Virgi., Cepat Mahir Pemrograman Web dengan PHP dan MySOL, Prestasi Pustakaraya, Jakarta, 2011.

[6] Huda, Miftahul., Membuat Aplikasi Database dengan Java, MySQL dan Netbeans, PT. Elex Media Komputindo, Jakarta, 2010.

[7] Sutanta, Edhy, Sistem Informasi Manajemen, Graha Ilmu, Yogyakarta, 2003.

[8] R. Tantra, Manajemen Proyek Sistem Informasi, Yogyakarta: ANDI, 2012

[9] Wahyono, Teguh., Practice Guide PHP OnWindows, PT. Elex Media Komputindo, Jakarta, 2009.

[10] Wiswakarma, Komang., 9 Langkah Menjadi Master Framework CodeIgniter., Loko Media, Yogyakarta, 2010. 